特集 6

\title{
食道の胃接合部の病態と手術一とくに食道アカラシア および逆流性食道炎に関する検討
}

\author{
山口大学医学部第 2 外科 \\ 村上 卓夫 足立淳 小佐々博明 \\ 岡正朗鈴木 敞
}

実験的検討より噴門部逆流防止機構のうち lower esophageal sphincter, 次いでWillis 胃斜走筋が 食道胃接合部高圧帯の形成に重要であると思われた。

逆流防止に重要な食道・胃接合部高王帯の再建には, Nissen 法についで Belsey Mark IV 法が有効 であることが判明した。

食道裂孔ヘルニア症例に対する胃底部固定と胃後方固定を追加した Nissen 法は静止内圧の上昇招 よび症状の軽減に有効であった。

アカラシフモデル犬は正常犬に比べて, 静止内圧の上昇, およびガストリンおよびセクレチンに対 する過敏反応を示した.

アカラシフモデル犬, アカラシア患者群では, 正常犬, 対照患者に比べて, VIP, Substans P 濃度 は有意に低かった。

アカラシア症例に対する Jekler and Lhotka method with long myectomyは, 静止内圧の減少お よび症状の軽减さらに逆流症状も認めず有効な術式と思われた。

Key words: lower esophageal sphincter, reflux esophagitis, esophageal achalasia

はじめに

食道・胃接合部には噴門括約筋機構が存在し, 胃か ら食道への逆流を防止している。食道・胃接合部の運 動機能異常として代表的なるのとしては逆流性食道炎 と食道アカラシアがある. 今回滑脱型食道裂孔へルニ アおよび食道フカラシアの外科的治療の際に問題とな る下部食道括約筋 (LES) を初めとする噴門括約機構 と消化管ホルモンの関連について, 実験的および臨床 的検討を加えた。

\section{1. 食道・胃接合部の逆流防止機構}

食道・胃接合部には噴門括約機構が存在し, 胃から 食道への逆流を防止している。噴門括約機構は, LES, Willis 胃斜走筋, 横隔膜右内脚, 横隔食道膜（横隔食 道靯帯), 食道胃接合部粘膜敏襞, 腹腔内食道分節, His 氏角(食道の胃内への開口部の外側に形成される角度)

*第35回日消外会総会シンポ $1 ・$ 食道・胃接合部の病態 と手術

$<1990$ 年 6 月 13 日受理 >別刷請求先 : 村上 卓夫

干755 宇部市小串1144 山口大学医学部第 2 外科
と胃泡の側圧などから構成されている゙．LESは食道 の末梢 $2 \sim 3 \mathrm{~cm}$ にあり, 解剖学的に食道の他の部位の 輸送筋と区別されないが，生理学的にその存在が確認 されている.種々の噴門括約機構構成因子のうち, LES が逆流防止に最も重要な役割を演してたり, His 氏角, 食道・胃接合部粘膜微譬がこれに次いでいるとしてい る2)3).

\section{2. 噴門括約機構構成因子に関する検討}

われわれは静脈麻酔のもとに雑種成犬を用いて，噴 門括約機構構成因子を個別的に破壊した後に open-tip 法によって, 食道・胃接合部静止内圧の变化を測定し た. 開腹のみの対照群では王值は $30.2 \mathrm{cmH}_{2} \mathrm{O}$, 横隔食 道勒帯のみを切離した群 ( I 群) では27.2 $\mathrm{cmH}_{2} \mathrm{O}$, 横 隔食道靬帯および LESを切離した群 (II 群)では15.0 $\mathrm{cmH}_{2} \mathrm{O}$, 横隔食道勤帯および Willis 胃斜走筋の切離 群 (III群) では22.8 $\mathrm{cmH}_{2} \mathrm{O}$, 横隔食道鞄帯, LES およ びWillis 胃斜走筋の切離群 (IV群) では $8.7 \mathrm{cmH}_{2} \mathrm{O}$ と 最も低かった，したがって，LES 次いでWillis 胃斜走 筋が食道・胃接合部高圧帯の形成に重要であることが 
Fig. 1 Influence of various procedure to cardiac component on the lower esophageal sphincter pressure. Control : laparotomy. group I : division of the phrenoesophageal ligament. group II : division of the phrenoesophageal ligament, and the LES. group III : division of the phrenoesophageal ligament, and the Willis' oblique muscle. group IV : division of the phrenoesophageal ligament, the LES and the Willis' oblique muscle.

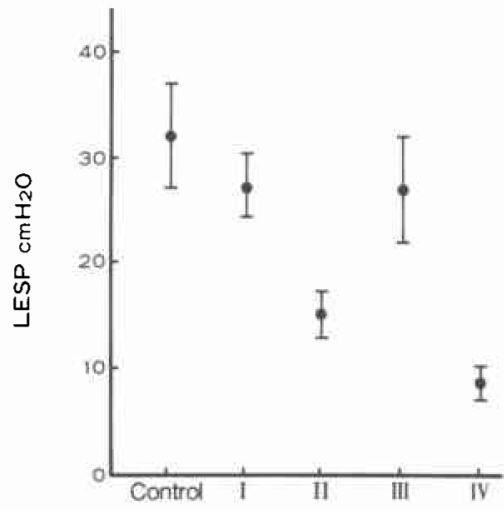

明らかとなった（Fig. 1).

次に噴門括約機構構成因子を個別的に破壊して作成 したイヌの各群にテトラガストリン $5 \mu \mathrm{g} / \mathrm{kg}$ を静注し て，外因性ガストリンに対する反応を検討したが開腹 のみの対照群におけるテトラガストリン静这後の内压 上昇を $100 \%$ とした場合，I 群では76\%，II群では16\%， III群では32\%，IV群では10\%の内圧上昇を示した。し たがって外因性ガストリンに対する感受性の低下は, 特にLESの切離, 次いでWillis 胃斜走筋の切離に よって著明に生ずることを示した。

3. 食道裂孔へルニアに対する各種術式の検討

雑種成犬に, 食道裂孔へルニアに対する各種の手術 術式を経腹的に施行し, 比較検討した, 術後の食道・ 胃接合部静止内圧は術前値に比べて, Harrinton 法で は4.9 $\mathrm{cmH}_{2} \mathrm{O}$, Hill 法では3. $4 \mathrm{cmH}_{2} \mathrm{O}$, Stensrud 法 $18.5 \mathrm{cmH}_{2} \mathrm{O}$, Belsey Mark IV では $18.0 \mathrm{cmH}_{2} \mathrm{O}$, Nissen 法では54.0 $\mathrm{cmH}_{2} \mathrm{O}$ と上昇した4)（Fig. 2).

またテトラガストリン $5 \mu \mathrm{g} / \mathrm{kg}$ 静注後の内王の上昇 は, Nissen 法, Belsey Mark IV 法, Harrington 法 の順に著明であり, Hill 法, Stensrub 法の術後にはむ しろテトラガストリンに対する過敏性が低下した。し たがって逆流防止に重要な食道・胃接合部高王帯の再 建にはNissen 法, ついで Belsey Mark IV 法が優れ ていると思われた。
Fig. 2 Changes of LESP after performance of various methods of hiatal herniorrhaphies. Comparing 5 kinds of hiatal herniorrhaphies in dogs, LESP increased postoperatively in the following order : Nissen, Belsey Mark IV, Stensrud, Hill and Harrington methods.

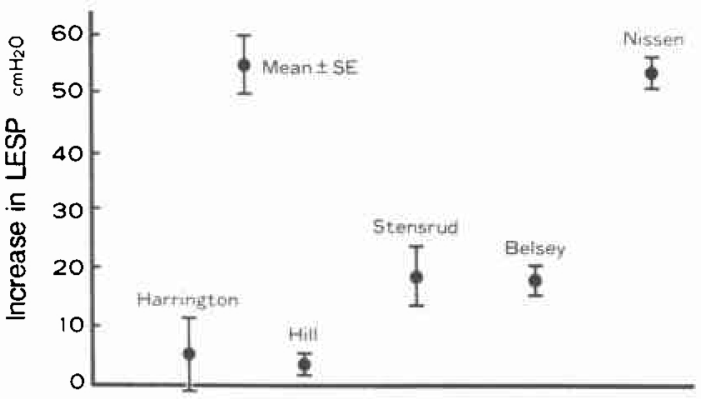

\section{4. 食道裂孔へルニアにおける臨床例の検討}

われわれは食道裂孔へルニア症例に対して，胃底部 固定と胃後方固定を追加した Nissen 変法を施行して きた．本術式における術前後の高王帯は24.9 $\mathrm{cmH}_{2} \mathrm{O}$, 長さ $5.1 \pm 3.5 \mathrm{cmH}_{2} \mathrm{O}$ から，術後にはそれそ

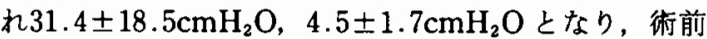
みられた二相性パターンす减少し，臨床症状，内視鏡 所見改善された。

5. 食道アカラシアにおける実験的検討

Deloyer 法による食道アカラシア様犬を作成して検 討した。 まず正常犬とアカラシフ様犬の静止内圧はそ れぞれ $28.0 \pm 2.7 \mathrm{cmH}_{2} \mathrm{O}, 32.5 \pm 3.8 \mathrm{cmH}_{2} \mathrm{O}$ でアカラ シア犬において上昇を認め，さらにガストリン刺激時 の内王は正常犬 $48.3 \pm 5.3 \mathrm{cmH}_{2} \mathrm{O}$, 食道アカラシア様 犬は $64.3 \pm 4.3 \mathrm{cmH}_{2} \mathrm{O}$ とアカラシア犬に打いて有意 に強いガストリンに対する過敏反応を示した（Fig. 3).

\section{6. 食道アカラシフ臨床例の検討}

われわれの教室の食道アカラシア症例の食道内圧の 検討では，術前の食道・胃接合部静止圧は42.73土23.3 $\mathrm{CmH}_{2} \mathrm{O}$ (正常15 20) と正常の二倍程度高く, 術前テ トラガストリン $5 \mu \mathrm{g} / \mathrm{kg}$ 静注後 5 分には下部食道内圧 は著明に上昇した（Table 1)，つぎにわれわれは LES の弛緩作用を持つセクレチン，VIP の作用を食道内圧 の面から検討した.ヒトに対するセクレチンの LES 弛 緩作用をコントロールとして 4 名の成人男子および 6 名の食道アカラシア患者について検討した。セクレチ ン $3 \mathrm{IU} / \mathrm{kg}$ の静注により両群とも LESP は有意に低下 した(Fig. 4). LESP 低下率は，静止内圧でVIP とセ 
Fig. 3 Comparison of LES pressure responses to intravenous tetragastrin $(5 \mu \mathrm{g} / \mathrm{kg})$ injection between normal dogs (controls) and achalasia dogs in which $5 \%$ phenol was injected in muscular layer of LES to destroy Auerbach's plexus. Achalasia dogs showed elevation of resting LES pressure and hypersensitive response to injection of tetragastrin $(p<0.05)$.

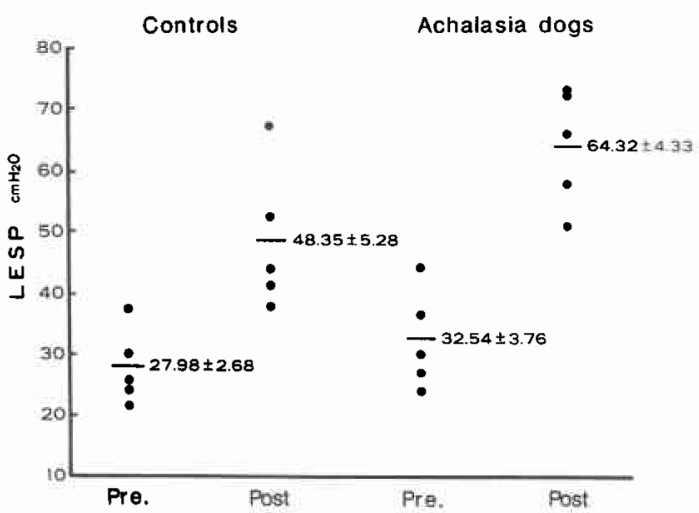

Table 1 Resting LES pressure in 11 patients with achalasia was $42.7 \pm 3.3 \mathrm{cmH}_{2} \mathrm{O}$. It increased significantly after intramuscular injection of $5 \mathrm{~g} /$ $\mathrm{kg}$ of tetragastrin and fluoroscopic observation showed the tonic contraction of the lower esophagus and cardia.

Pressure of $\mathrm{HPZ}$ (High pressure zone)

: $42.7 \pm 3.3 \mathrm{cmH}_{2} \mathrm{O}$ (normal range $15 \sim 20 \mathrm{cmH}_{2} \mathrm{O}$ ) $(\mathrm{n}=11)$ mean $\pm \mathrm{SE}$

Intrathoracic esophageal pressure : $3 \sim 8 \mathrm{cmH}_{2} \mathrm{O}$ (normal $4.5 \mathrm{cmH}_{2} \mathrm{O}$ ) T.G $(5 \mu \mathrm{g} / \mathrm{kg})$

\begin{tabular}{l|c|c|c|c}
\hline Response & - & + & H & H \\
\hline Cases & 1 & 2 & 3 & 4 \\
\hline
\end{tabular}

クレチンで $5 ： 1$, テトラガストリン刺激下で $7 ： 1$ であっだ). また免疫組織学的検討から LES 筋層にお ける VIP 細胞の著明な减少を認めた。 RIA (radioimmunoassay)による定量でるVIP の低下を認めた。こ のように LES の強力な弛緩作用をるつVIP 細胞の減 少か，食道アカラシアの弛緩不全に関与していると考 えられた。

LES 筋層中の VIP, substance Pを定量したとこ ろ, アカラシアモデル犬, アカラシア患者群では，正 常犬, 対照患者に比べて, VIP, substance Pいずれる 有意に濃度の低下を認めた（Fig. 5).

7.われわれが行っている Jekler and Lhotka
Fig. 4 In four healthy volunteers and six achalasia patients, LESP was reduced after injection of $3 I U / \mathrm{kg}$ secretin $(\mathrm{p}<0.05)$. Achalasia patients showed a hypersensitive response to secretin $(p<0.01)$.

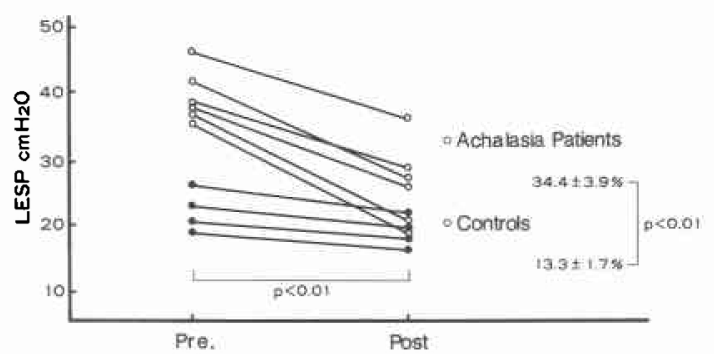

Fig. 5 Radioimmunoassay of the concentration of substance $\mathrm{p}$ and VIP (hormone (ng)/protein $(g) \times 10)$ in the lower esophageal muscular layer of achalasia dogs and patients was significantly less than in control dogs and patients.

(Dogs)

(Patients)

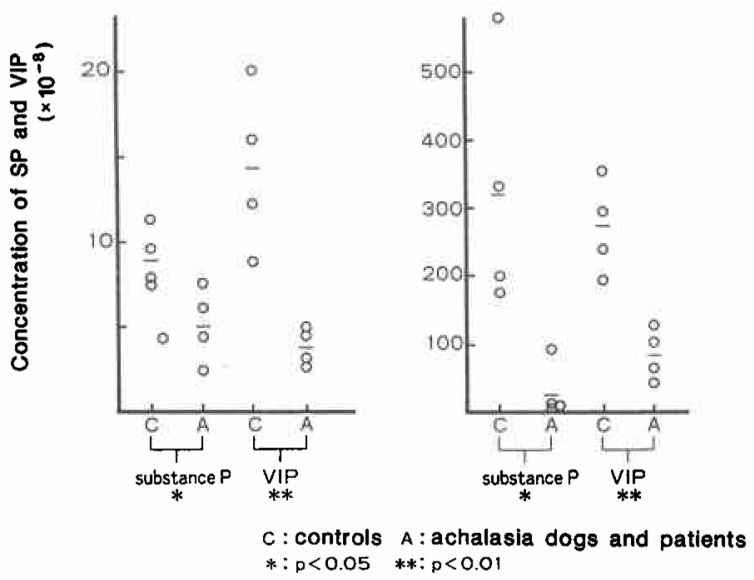

method with long myectomy

Jekler and Lhotka 法6) は, Helle 氏粘膜外食道噴門 筋輪切開術の変法であり, 筋輪切開創に胃底部前壁鼎 膜面をパッチ䋖合する方法である，われわれは筋輪切 開するとともに, 約 $0.5 \sim 1.0 \mathrm{~cm}$ 幅, 長さ $6 \sim 7 \mathrm{~cm}$ の食 道下端筋層を切除する方法を付加している。これによ り粘膜露出部が1/3からほぼ1/2近くまでなることによ り，術後の再狭窄を防止する。また露出粘膜下層面が 胃底部前壁獎膜面で確実におおわれるために周囲との 窟着の発生が防止され, His 氏角(食道の胃内への鋭角 をるっての開口)が鋭角化され，Gubaroff 氏弁が延長， 
強調され，粘膜が損傷された時も安全で，術後这流， 滑脱型食道裂孔へルニア, 膨出性食道䕀室などの発生 を防止しらる.したがってこの術式を施行した際には， 術後 X 線検查では造影剤の噴門部の通過は良好で, 食 道の払張は軽减し, Trendelenburg 体位でも造影剤の 胃食道逆流は証明されず，自覚的にも逆流性食道炎の 症状は認められない。

\section{考 察}

LES と消化管ホルモンとの関連について, Castell ら》は，ガストリン様 penta-peptide の submaximal does の皮下注射後には，LESP は著しく上昇し，histalog やアルカリの胃内注入後も上昇したが, $0.1 \mathrm{~N}$ 塩 酸の胃内注入後には低下したとしている。 また Lipshutz ら ${ }^{8)}$ にると，ガストリン I は, acetylcholineや norepinephrineより10倍近い低濃度で LES に最大反 応を生じ，その閾値量は付近の食道や胃より100倍も低 かったとしている．胃内酸度の減少はガストリンの放 出を促してLESPを上昇させ，また逆に胃内酸度の増 加はガストリン放出を抑制してLESPを低下させる。

Cohen ら9によよる，十二指腸の酸性化によって内 因性に放出されるか，静注で投与されたセクレチンは ガストリンIに対する LES の最大反応を著明に低下 させた、コレチストキニン,グルカゴン, VIP, GIPな ぞもガストリンの LES に対する作用に搭抗的に働く.

ヒトのLESPに対する各種ホルモンの作用は, 外因 性のそれらと，内因性のそれらとの間に差異があると の報告がある。

ホルモン剂とくにグルカーゴンは，大量に静注され ると、ヒトおよびイ邓の LESPを一過性に低下させ る、またペンタガストリンによって刺激された LESP は，小量のグルカーゴンによって一過性に低下すると の報告すある。近年 VIP が神経伝達物質として，また 直接笳肉に働いて LES 収縮を抑制することが注目さ れてきた。 われわれの VIP に関する検討では, (1) VIP はセクレチンに比べて 5 倍の正常犬 LES に対する弛 緩作用を示す。 (2) VIP はセクレチンに比べて 7 倍のガ ストリンによる LES 収縮に対する抑制効果を示す。(3) 食道アカラシフ犬では正常犬に比べて約 2 倍の VIP による他緩作用がみられる。(4)食道アカラシア患者は 正常人に比べて，より過敏な外因性セクレチンによる LES 弛緩作用を示す。（5)食道アカラシア犬および食道 アカラシア患者の LES, とくに Auerbach 神経叢にお いてはPAP法でVIP 抗体に反応する神経繊維およ び神経細胞が著明に減少しておりここのことが LESの
弛緩不全に関係している可能性があることなどが明ら かになった。したがって VIP も食道フカラシアの治療 に用いられる可能性がある。

食道アカラシア患者の LES にある受容体は内因性 ガストリンに対して過敏性を示すことが，LESの hypertensiveの大きな原因であるとの報告もあ $3^{10)}$.

食道アカラシア患者において LESPが高いことは, 食道空虚化の傷害に大きな役割を演じていると思われ る。またLESの弛緩は起こるが，通常の 2 倍ある LESP を下げるに十分でなく，その結果機能的食道下 部の閉塞状態をきたす。 そして近位側食道は㧪張し， 末梢側は先細りとなり，拡張が著明となると megaesohagus の状態となる。食道筋輪層の肥厚をきたしたり， また 2 次的な食道炎をきたし，時には粘膜に潰瘍性病 変を伴らことすある。

食道アカラシアの手術療法としては, Heller 粘膜外 食道噴門筋輪切離術が行われたが，筋層の不十分な切 離による讌下困難の再発，15.6 40\%にみられる胃食 道逆流による逆流性食道炎の発生が起こり，治療成樍 は必ずしも良好ではなかったため，種々の術式が考案 され用いられてきた。われわれは Jekler and Lhotka method with long myectomyを施行しておりほぼ満 足する結果をえている。

食道疾患における手術操作の有効性の判定の目的 で, 術中に内瓦測定を行ら方法を Hill ら ${ }^{11)}$ が報告し, 食道運動機能障害 (achalasia, diffuse spasmus, segmental esophageal spasmus) の手術時に, 食道の myotomy の確実性を判断するのに術中内圧測定を行 い, 94\%に臨床的改善をみたとしている，われわれは 食道裂孔へルニアや食道アカラシア症例においては, 麻醉時, 開腹時, myotomy and myectomy 後, 逆流 防止術付加後, 手術終了時とそれぞれ内圧測定を行っ ている。術中内圧測定の意義は，手術効果の客観的評 価の一つとして用いられ，さらに術後成績を正確に予 測するのに有効である.

食道裂孔へルニアの合併がある場合に，また裂孔一 ルニアが存在しなくても，逆流性食道炎をきたすとの 報告もあり ${ }^{12)}$ ，その判定には食道・胃 $\mathrm{pH}$ 測定が有用で

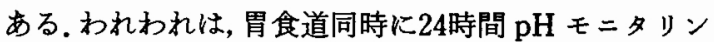
グを行って逆流の判定を行っている.

われわれの食道アカラシア患者に打ける術前後の 24 時間 $\mathrm{pH}$ の所見では，術後においては逆流も認めず術 前とほぼ同様のパターンを呈していた。 
食道運動障害の検索に $99 \mathrm{~m}$ Technetium を含んだ喠 液状塊の通過をコンピューターを用いて分析する方法 （RT）垯速，簡便，非侵襲的かつ高感度であると報 告されている(13). しかし一方 Murshal ら ${ }^{14)}$ は，食道内 压とRTを比較検討した結果からスクリーニングテ ストとしての RT 法の有用性は見いだしえなかった としている。

99mTCでラベルした粥を用いた食道シンチに打け る術前症例では，やや停滞ぎみで食道から贯内への排 出は30分後に起こっていた。

術後は食道から胃内への排出は, 比較的スムーズに なって扣り，著明に改善されていた。

\section{文献}

1）石上浩一, 村上卓夫, 水田英司ほか：食道噴門部の 括約機構. 外科治療 $47: 149-159,1982$

2) Botha GSM : The gastroesophageal junction, 1st edition, J. \& A. Churchill Ltd., London, 1962, p285-300

3) Payne WS, Olsen AM.: The esophagus. 1st edition, Lea \& Febiger, Philadelphia, 1974, p107 $-114$

4) Okazaki Y : Experimental and clinical studies on the operative treatment of sliding esophageal hiatal hernia. Arch Jpn Chir 49:3-36, 1980

5）丹黒 章：噴門括約機構におけるVIPの関与と 食道アラカシアの病態生理. Arch Jpn Chir 55:81 $-95,1986$

6) Jekler, J, Lhotka J: Modified Heller procedure to prevent post operative reflux eso- phagitis in patient with achalasia. Am J. surgery $113: 251-254,1967$

7) Castell DO, Harris LD: Hormonal control of gastroesophageal-sphincter strength. N Engl J Med 282: 886-889, 1970

8) Lipshutz W, Cohen S: Physiological determinants of lower esophageal sphincter function. Gastroenterology $61: 16-24,1971$

9) Cohen S, Lipshutz W, Hughes W: Pole of gastrin supersensitivity in the pathogenesis of lower esophageal sphincter hypertension in achalasia. J Clin Invest $50: 1241-1247,1971$

10) Cohen $S$, Lipshutz W: Hormonal regulation of human lower esophageal sphincter competence; Interaction of gastrin and secretin. J. Clin Invest $50: 449-454,1971$

11) Hill LD: Intraoperative measurement of lower esophageal sphincter pressure. J Thorac Cardiovasc Surg 75: 375-382, 1978

12) Vitale GC, Cheadle WG: Computerized 24hour ambulatory esophageal $\mathrm{pH}$ monitoring and esophagogastroduodenoscopy in reflux patient: A comparative study. Ann Surg 200 : $724-728,1984$

13) Fisher RS, Malmud LS, Roberts GS et al: Gastroesophageal (GE) scintiscanning to detect and quantitate GE reflux. Gastroenterology 70 : $301-308,1976$

14) Mughal MM, Marples M, Bancewicz J : Scintigraphic assessment of esophageal motility: What does it show and How reliable is it? Gut $27: 946-953,1986$

\section{Experimental and Clinical Studies on the Operative Treatment of Sliding Esophageal Hiatal Hernia and Achalasia of the Esophagus}

Takuo Murakami, Hiroaki Ozasa, Atsushi Adachi, Masaaki Oka and Takashi Suzuki Second Department of Surgery, Yamaguchi University School of Medicine

Among the components of the antireflux of the cardia in dogs, the lower esohageal sphincter (LES) is the most important and Willis' oblique muscle is next. In a comparison of 5 kinds of hiatal herniorrhaphies in dogs, LES pressure (LESP) increased after the operation in the following order; Nissen, Belsey Mark IV, Stensrud, Hill and Harrington methods. Responses to tetragastrin tended to increase after the Nissen and Belsey Mark IV procedures. No recurrences and no complications, such as fundoplication disruption, dysphagia and gas bloat syndrome, occurred in the 23 patients who undergone modified Nissen fundoplication at our clinic. The mean LESP increased from $27.2 \pm 2.8 \mathrm{cmH}_{2} \mathrm{O}$ preoperatively to $37.5 \pm 3.6 \mathrm{cmH}_{2} \mathrm{O}$ postoperatively. The effect of gastrointestinal hormones such as gastrin, secretin, VIP and substance $P$ on LES were investigated in normal dogs, dogs with phenol-injected achalasia, normal patient and achalasia patients. Increase in the LESP response to tetragastrin injection was statistically greater in the achalasia dogs than in normal dogs. Increase in LESP response to tetragastrin was inhibited by previous injection of secretin in both normal and achalasia dogs. Radioimmunoassay revealed a decrease in VIP and substance P concentrations in the lower esophageal muscular layer in both achalasia dogs and 
patients. In patients with achalasia, the LESP increased significantly after intramuscular injection of tetragastrin at a dose of $5 \mu \mathrm{g} / \mathrm{kg}$. The Jekler and Lhotka method with long myectomy proved to be an excellent surgical procedure for achalasia of the esophagus because disturbance in passage was improved and then suitable high pressure zone to prevent postoperative reflux esophgitis was recostructed at the gastroesophageal junction.

Reprint requests: Takuo Murakami The Seocnd Department of Surgery, Yamaguchi University School of Medicine

1144 Kogushi, Ube, 755 JAPAN 